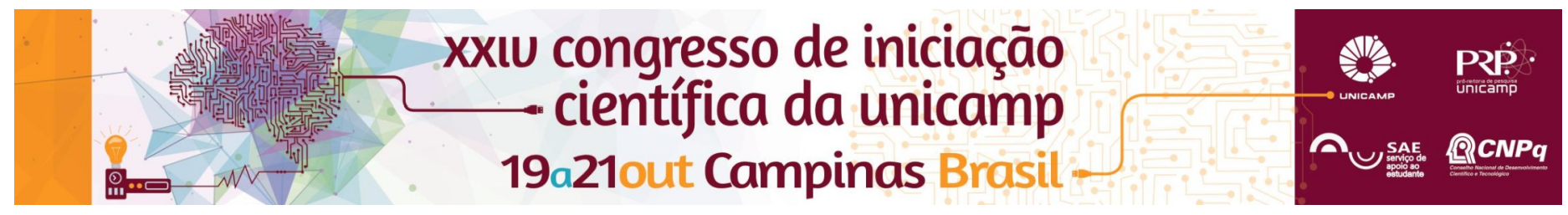

\title{
PANORAMA DA GINÁSTICA PARA TODOS NO BRASIL: UMA PERSPECTIVA DAS FEDERAÇÕES ESTADUAIS
}

\section{Isabela F. Massaro*, Eliana de Toledo.}

\begin{abstract}
Resumo
Nota-se no país, por uma análise geral dos 7 Anais do Fórum Internacional de Ginástica Geral (2001-2014), que há muitos estados que desenvolvem aulas, cursos, projetos e trabalhos científicos acerca da Ginástica Para Todos (GPT), nos mais diversos contextos de prática, como clubes, escolas, ONGs, faculdades etc. No entanto, há pouquíssimos estudos que tracem um panorama da GPT brasileira. Nesse contexto, nosso objetivo é traçar um panorama da GPT apenas no âmbito federativo a partir das Federações Estaduais ligadas à CBG.
\end{abstract}

\section{Palavras-chave:}

Ginástica Para Todos, Federações de Ginástica, Gestão Federativa.

\section{Introdução}

Há estados do Brasil que desenvolvem ações acerca da GPT, nos mais diversos contextos de prática. Porém funcionam com dificuldade por possuírem recursos restritos, desse modo as federações possuem um papel importante de colaborar pra democratizar a prática e veicular a GPT. Tornando-se, portanto, nosso objetivo de pesquisa. E é nesse cenário que situa-se o problema de pesquisa que objetiva mapear as modalidades gímnicas, predominando a GPT, pelo país por meio de cada federação, para que possamos fazer estatísticas da prática de GPT no país e ter a capacidade de avaliar regiões com destaque na GPT para aprimorá-la cada vez mais, como também incentivar as regiões que não tenham uma presença forte da GPT, a possuírem projetos de iniciação ao meio ginástico. Porém, "[...]o acesso à informação sobre a GPT nessas federações é relativamente difícil, pois apenas seis federações, das vinte e três existentes, possuem site oficial." (MASSARO e TOLEDO, 2015). Isso dificulta o desenvolvimento de pesquisas e os planos de gestão do comitê de GPT da Confederação Brasileira de Ginástica (CBG), para ambos melhor desenvolvê-la no país.

\section{Resultados e Discussão}

A pesquisa é essencialmente exploratória, ou seja, uma pesquisa de campo utilizando como ferramenta a aplicação de questionário. Ele é composto por perguntas que avaliarão quantas federações brasileiras de ginástica possuem a GPT. Nosso universo da pesquisa são as 21 federações brasileiras, contactadas por e-mail via CBG, e dentre as 21 somente uma retornou até junho de 2016. Deste único questionário, há indicativos de que somente uma entidade é filiada, e que essa Federação não possui um comitê de GPT. Até a data do congresso esperamos ter mais respostas e apresentar um trabalho mais sólido. Contudo, a pesquisa progrediu desde seu início, parte dela já foi apresentada em forma de banner num congresso de desporto, que mostrava as ginásticas praticadas no Brasil(Tabela 1).

Tabela 1. As ginásticas praticadas nas Federações

\begin{tabular}{|l|l|}
\hline & Não possui federação \\
\hline & Não possui site e/ou rede social \\
\hline & Possui site e/ou rede social \\
\hline
\end{tabular}

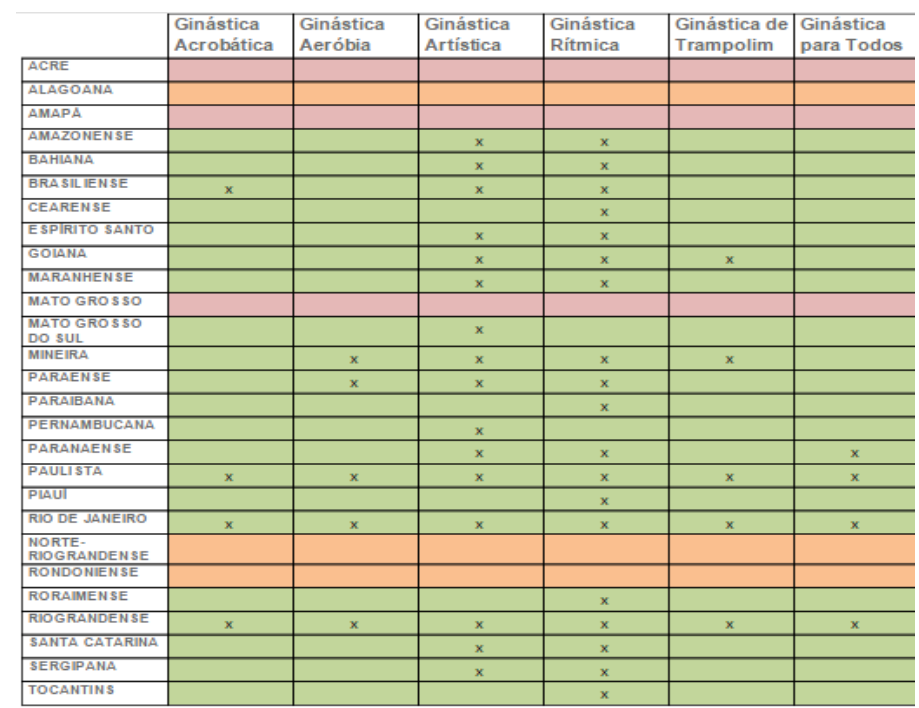

Das 21 federações analisadas, foi possível observar a presença da ginástica rítmica em 19 delas, sendo 90,5\% da modalidade presente no Brasil. A ginástica artística segue com 76,2\%, estando presente em 16 federações. As ginásticas aeróbia e de trampolim estão em $23,8 \%$ do Brasil. A GPT e a acrobática são as que menos se destacam, possuindo presença em apenas $19 \%$ do país.

\section{Conclusão}

A aprovação da presidência da CBG, e o apoio da presidente do comitê de GPT foram fundamentais para esta pesquisa. Com esse apoio ainda temos esperança de obter mais respostas e também de realizar pesquisas futuras com a CBG e a GPT.

$\overline{\text { CONFEDERAÇÃO BRASILEIRA DE GINÁSTICA (www.cbginastica.com.br }>>}$ acessado em Fevereiro de 2015).

PAOLIELLO, E.; TOLEDO, E.; AYOUB, E.; BORTOLETO, M. A. C.; GRANER

L.. Grupo Ginástico Unicamp: 25 anos. Campinas: Editora da Unicamp, 2014.

SANTOS e SANTOS. História da Ginástica Geral no Brasil. Rio de Janeiro, 1999. p.10.

TOLEDO, E.; SCHIAVON, L. M.. Ginástica Geral: diversidade e identidade. In: PAOLIELLO, Elizabeth (org). Ginástica Geral: experiências e reflexões. São Paulo: Phorte, 2008. p.217-238. 